\title{
The Relationship between Personality, Organizational Culture and Emotional Intelligence to Performance
}

\author{
Budi Harni, Soewarto Hardhienata, M. Entang \\ Post Graduate Program, Universitas Pakuan Bogor, Indonesia
}

\begin{abstract}
The aim of this study is to examine the influence of Personality, Organizational Culture, and Emotional Intelligence to Performance of lecturers either individually or simultaneously. Variables of Personality, Organizational Culture, and Emotional Intelligence serve as independent variables while the dependent variable is Performance. The research was conducted on proportional randomly selected 107 lecturers of three (3) private Colleges of Economic Science in Bogor, West Java Province, Indonesia. Using mix method, the sequential explanatory design is applied where quantitative come first. The study both quantitatively and qualitatively reveals that there is a positive significant relationship among variables under the following distribution of coefficient of correlation: Personality to lecturers' performance $=0.667$, Organizational Culture to lecturers' performance $=0.324$, Emotional Intelligence to lecturers $=0.632$, and when tested together it produces coefficient of determination $=0.514$ indicating the existence of other $48.6 \%$ variables not including in the model affecting lecturers' performance
\end{abstract}

Keywords: Personality, Organizational Culture, Emotional Intelligence, Performance

\section{INTRODUCTION}

The performance of lecturers is one important factor in the progress of a university. The performance of lecturers becomes very important because the decline in performance of both individuals and groups within a college can have a meaningful impact in a college. So, in this case, a leader has a quite heavy task where he should always try to improve performance and provide motivation for subordinates in order to improve their performance to achieve the goals of the college.

One of the goals of college is to produce qualified graduates so that the purpose of a university can be achieved then the college must have a high lecturers' performance. Therefore, through scientific research, it will be disclosed the Relationship between Personality, Organizational Culture and Emotional Intelligence with the Performance of lecturers at College of Economics Science in the city of Bogor. Based on the data of lecturers, activities taken in 2010/2012 and 2012/2013, it can be concluded that the lecturer's activity level is only $57 \%$ in addition to achievement below $80 \%$, also shows the decrease of lecturers activity and tends to decrease. Based on the background and restriction issues to be examined in this study, it is formulated main points as follows:

1. Is there a relationship between Personality and Performance?

2. Is there a relationship between Organizational Culture and Performance?

3. Is there a relationship between Emotional Intelligence and Performance?

4. Is there any simultaneous relationship among Personality, Organizational Culture, Emotional Intelligence to Performance?

\section{LiteratURE REVIEW}

Colquit et.al (2009: 37), suggests performance is the value of a set of employee behaviors that contribute positively or negatively to achieving organizational goals. Basically, performance has three dimensions: (a) task behavior, (b) moral behavior, and (c) challenging behavior. Task behavior is the behavior of employees who directly involved in transforming the source of the organization in virtue, service or production of the organization. Moral Behavior is the activity of volunteerism of employees whether there is a reward or not to still contribute to the organization to improve the overall quality of the workplace. Challenging Behavior is the behavior of employees who deliberately are blocking the 
achievement of goals like sabotage, theft, waste of resources, corruption, gossip, harassment, cruel treatment (torture).

Within this research, the measurement indicators for lecturers include 1) preparation of lesson plans, 2) learning output 3). learning outcomes 4 ) evaluation, 5) report generation.

Personality definition according to Robbins (2010: 45,47) is a unique combination of emotional patterns, thoughts, and behaviors that affect how a person reacts to situations and interacts with others. Personality is often depicted in measurable traits that are shown by a person. In the Big Five Model five-dimensional personality include:

1. Extraversion: The degree to which a person is friendly, happy to talk, and firm

2. Agreeableness: The degree to which a person is good, cooperative, and trustworthy.

3. Conscientiousness: The degree to which a person is responsible, dependable, persistent, and achievement oriented.

4. Emotional stability: The degree to which a person is calm, enthusiastic, and safe (positive) or calm, anxious, depressive, and insecure (negative)

5. Openness to experience: The degree to which a person is imaginative, sensitively artistic, and knowledgeable

Thus, the indicators are 1) Openness to experience 2) Conscientiousness 3), Extraversion,4) Agreeableness 5) Emotional stability.

According to Kusdi (2011: 11) culture is a pattern of behavior, attitudes, values, and assumptions that members of an organization have socialized to new members, and are somewhat stable over time. In general, culture experts divide it into three layers based on their depth, i.e. artifacts, values, and assumptions. In addition, to describe the characteristics of culture in an organization, some experts suggest certain typologies that describe the types of culture.

According to Gibson, et al (2012: 31), organizational culture is how workers perceive and how these perceptions create patterns of beliefs, values, and expectations. This definition shows the culture that involves; (A) assumptions, (b) adaptations, (c) perceptions, and (d) learning. He further argues that organizational culture consists of artifacts and creation, values, and basic assumptions that include the relationship with the environment, the reality of nature, time, space, natural life, the activities of the natural life, and the relationship between the natural life. This way. Organizational culture is measured by indicators: 1). norms of organizational behavior, 2) trust of organizational members 3) organizational patterns, 4) incentives to innovate 5) orientation of objectives.

Zeidner et al (2009: 25) suggests that emotional intelligence theories are divided into three ways of understanding emotional intelligence, one of which is, trait emotional intelligence - a whole personality factor that represents self-emotion, so that an individual has a related personality directly with emotional functions, such as self-confidence, assertiveness, and empathy. Stephen R. Covey (2005: 76) reveals that emotional intelligence is, self-awareness, social sensitivity, empathy, and efforts to communicate well with others. Emotional intelligence is the sensitivity of timing, social appropriateness, and courage to recognize weaknesses, express and respect differences. Stephen R. Covey explains that there are five main components of emotional intelligence that have been commonly accepted: a) self-awareness: the reflection of one's own life, and uses that knowledge to improve oneself, and to overcome weaknesses. B) personal motivation that is related to what triggers a person's spirit, vision, values, goals, hopes, desires, and passions that become a priority. C) selfregulation is managing oneself to achieve personal vision and values. D) empathy is to understand how other people perceive and feel things. e) socialization and communication, which is related to how to overcome differences, solve problems, produce creative solutions and interact optimally to pursue common goals. This way, in this research the indicators of emotional intelligence include: 1), identifying emotions, 2) managing emotions, 3) recognizing the emotions of others, 4) selfmotivation, 5) managing the emotions of oneself and others.

Based on the study of the theory described above, the following hypothesis is formulated:

1. There is a positive relationship between personality and lecturers' performance.

2. There is a positive relationship between organizational culture and lecturers' performance. 
3. There is a positive relationship between emotional intelligence and and lecturers' performance.

4. There is a positive relationship between personality, organizational culture, and emotional intelligence simultaneously with the lecturers' performance.

\section{Methodology}

This study applies Sequential Explanatory Design Mixed Method where the quantitative study is ahead of the qualitative study to examine the relationship between variables tested in the study using three independent variables through data obtained from questionnaires. The independent variable is personality $\left(\mathrm{X}_{1}\right)$, organizational culture $\left(\mathrm{X}_{2}\right)$, and emotional intelligence $\left(\mathrm{X}_{3}\right)$, while the dependent variable is the lecturers' performance $(\mathrm{Y})$.

The relationship among variables in the study described in Fig.1 below:

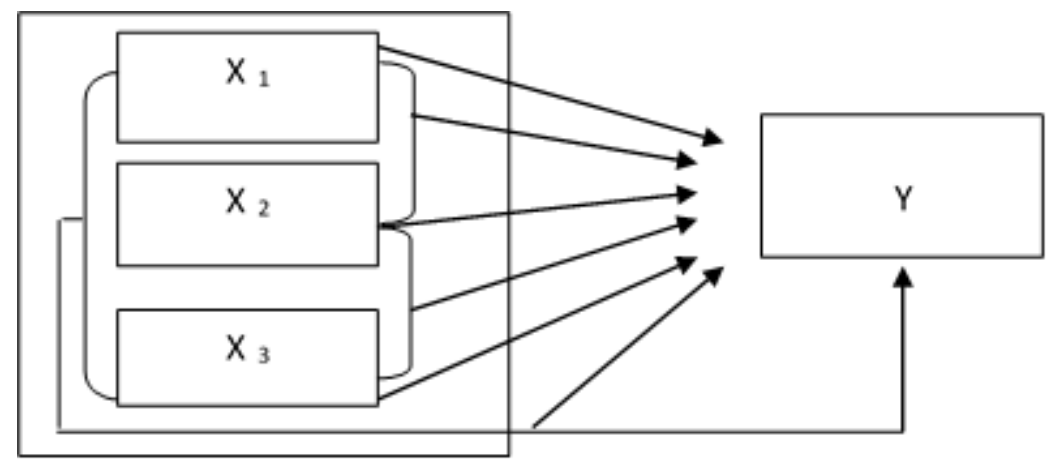

Figure1. Theoretical framework

Where,

$\mathrm{Y}=$ lecturers' performance

$\mathrm{X}_{1}=$ personality

$\mathrm{X}_{2}=$ emotional intelligence

$\mathrm{X}_{3}=$ emotional intelligence

The sampling technique is to count the number of samples by using the Slovin's formula generating samples obtained as many as 107 respondents out of 146 lecturers. Hypothesis testing is conducted by using regression analysis to determine the influence of one or more independent variables on the dependent variable. The normality assumption with Liliefors test are prerequisites to proceeding to further test. Hypothesis testing is performed at a significance level of 0.05 .

Qualitative study for the purpose of confirmation was performed through observation and interview to key informants as well as conducting focus group discussion with chairman of the colleges and lecturers.

\section{RESUlt AND DISCUSSION}

The teachers of listed organizations were asked to participate in the survey by responding their opinions for four different measures in Personality, Organizational Culture, Emotional Intelligence and Lecturers' Performance. Data is normal as the value of each variable $=0.0738,0.0797,0.0741$ below the critical value Liliefors test for $\mathrm{N}=107$ which is 0.0812 .

\subsection{Personality and Lecturers' Performance}

The result of hypothesis testing shows that functional relationship between $\mathrm{X}_{1}$ and $\mathrm{Y}$ is presented in the form of simple regression equation: $Y=21.04+0,83 \mathrm{X}_{1}$, with correlation coefficient value $=$ 0.677 and coefficient of determination $=0.458$ with significant level of 0.05 . This means that $45.8 \%$ variations of lecturers' performance can be explained by personality, while $54.2 \%$ is contributed by other variables that have correlation with lecturers' performance improvement. The result supports previous research of Suharto (2011), "Relationship between Principal Leadership and Personality Competence with Teacher Performance" with correlation coefficient $=0.8145$ and coefficient of determination $=0.458$ concluding that there is a significant positive relationship between personality 
with lecturers' performance. This means the higher the score of personality the higher the score of lecturers' performance thus the results of this study increasingly support the results of previous research on the positive relationship personality with lecturers' performance. Similarly, based on qualitative analysis through observation, interview, Focus Group Discussion (FGD) document review, it can be seen that there is a relationship between personality with lecturers' performance. This reinforces the results of quantitative research that proves significantly the first hypothesis of this study that there is a positive relationship between personality with lecturer performance.

\subsection{Organizational Cultures and Lecturers' Performance}

The result of hypothesis testing shows that the functional relationship between $\mathrm{X}_{2}$ and $\mathrm{Y}$ is presented in the form of simple regression equation $\hat{Y}=59.3+0.54 \mathrm{X}_{2}$, correlation coefficient $=0,324$ and coefficient of determination $=0,105$ with significant level of 0.05 . This means $10.5 \%$ Lecturers' performance is caused by the organizational culture, while $89.5 \%$ is contributed by other variables that have correlation with lecturers' performance improvement. This supports Subekti Wirawan (2010) "Organization with Teacher Performance" with correlation coefficient $=0.3592$ and coefficient $=$ 0.1290. Similarly, based on qualitative analysis through observation, interview, FGD document review, it can be seen that there is a relationship between organizational culture with lecturers' performance. This reinforces the results of quantitative research that proves significantly the second hypothesis that there is a positive relationship between organizational culture with lecturers' performance.

\subsection{Emotional Intelligence and Lecturers's Performance}

The result of hypothesis testing shows that the functional relationship between $\mathrm{X}_{3}$ and $\mathrm{Y}$ is presented in the form of simple regression equation: $\hat{Y}=27.86+0.8 \mathrm{X}_{3}$ with correlation coefficient $=0.632$ and the coefficient of determination $=0.400$. It means that $40 \%$ variation of lecturers' performance can be explained by emotional intelligence, while $60 \%$ is contributed by other variables that have correlation with lecturers' performance improvement. The results of this research supports Paiman, (2009) that there is a positive relationship between emotional intelligence with teacher performance with correlation coefficient $=0.4333$. Thus the results of this study further support the results of previous research on the existence of a positive relationship with the performance of lecturers. Similarly, based on qualitative analysis through observation, interview, FGD document review, it can be seen that there is a relationship of emotional intelligence with lecturers' performance reinforcing the result of quantitative research that every increase in an independent variable will improve lecturers' performance.

\subsection{Personality, Organizational Culture and Emotional Intelligence to Lecturers' Performance}

The result of hypothesis testing shows that the functional relationship between $\mathrm{X}_{1}, \mathrm{X}_{2}$ and $\mathrm{X}_{3}$ with $\mathrm{Y}$ is presented in the form of multiple regression equations: $Y=32.19 \mathrm{X}_{1}+0.34 \mathrm{X}_{2}+0.44 \mathrm{X}_{3}$. Since the significant level $=0.05$ and it can be concluded that the relationship between Personality variable $\left(\mathrm{X}_{1}\right)$, Organizational Culture $\left(\mathrm{X}_{2}\right)$ and Emotional Intelligence $\left(\mathrm{X}_{3}\right)$ together with Lecturer Performance is positive and significant.

The result for the coefficient determination is 0.514 meaning that $51.4 \%$ variation of Lecturers' Performance variable can be explained by variables of Personality, Organizational Culture and Emotional Intelligence simultaneously while $48.6,4 \%$ donated by other variables that do not include in the model.

The findings in this study indicate that if the lecturer performing his duties and functions are able to create, familiarize and develop the personality well and apply the organizational culture in himself and in organizational well and able to organize the emotional intelligence, they will be able to improve performance. This is in line with the theory put forward by James Gibson et.al (2012), Stephen Robbins (2010), Jerald Greenberg \& Robert A. Baron (2008) that define organizational culture as a cognitive framework consisting of attitudes, values, behavioral norms, and shared expectations of members of the organization

While the theory of Emotional Intelligence by Zeidner et.al (2004) that emotional intelligence as a trait, is a whole personality factor that represents self-emotion making an individual has a personality associated with emotional functions such as self-confidence, assertiveness and empathy.

the pattern of relationship that can be seen from the results of this study is the correlation between Personality with Lecturer Performance is $r=0.677$, Organizational Culture with Lecturer Performance 
is $=0.324$ and Emotional Intelligence with Lecturer Performance is 0.632 showing similar tendency that these three independent variables together contribute to the improvement of Lecturers' Performance.

Another contributing factor of $48.6 \%$ was revealed through the focus of the qualitative research: what are other factors outside personality, organizational culture and emotional intelligence affecting the performance of lecturers at the College of Economics in the city of Bogor? The findings of other factors that allegedly contribute to the achievement of lecturer's performance based on observations, interviews and documentation of qualitative research in the field are 1) Leadership of STIE Chairman, 2) Motivation of lecturer, 3) Other personality traits beside the big five.

\section{CONCLUSION}

The findings prove that there is a positive and significant relationship between personality, on lecturers' performance, organizational culture on lecturers' performance and emotional intelligence on lecturers' performance among non-permanent lectures working in colleges of economics science located in Bogor, West Java, Indonesia. With particular reference to initial design of the interaction among variables, the results showed that the contribution of personality variable on performance is $45.8 \%$, organizational culture is $10.5 \%$ and emotional intelligence is $40 \%$ indicating the highest individual contribution to the performance of non-permanent lecturers is personality. When combined together, contribution of the three variables of personality, organizational culture and emotional intelligence achieve $51.4 \%$ indicating the contribution of other variables not included in the model to predict performance of non-permanent lectures of colleges of economics science are $48.6 \%$. Those variables may include working motivation, working environment, disciplines, work satisfaction, commitment and work climate.

\section{REFERENCES}

[1] Colquit, Jason A. Jeffrey A, Lepine and Michael J. Wesson, 2009, Organizational Improving Commitment in the Workplace, New York McGraw-Hill/Irwin.

[2] Gibson, James L., John M. Ivancevich, James H. Donnelly, Jr., Robert Konospake, 2012. Organizations Behaviour, Structure, Process, Fourteenth Edition Singapore: The McGraw-Hill Companies.

[3] Jerald Greenberg \& Robert A. Baron Behaviour in Organizations, 2009, New Jersey: Pearson International, Inc.

[4] Kusdi, Budaya Organisasi, 2011, Jakarta, Penerbit Salemba Empat.

[5] Paiman, Hubungan antara Kecerdasan Emosional Dan Kreativitas Mengajar dengan Kinerja Guru, 2009, Bogor :Program Pasca Sarjana UNPAK.

[6] Stepehn R. Covey. The 8th Habit Terjemahan Zei Isa, 2005, Jakarta: PT Gramedia.

[7] Stephen P. Robbins, Manajemen, 2010, (Edisi Kesepuluh, Jilid 2), Penerbit: Erlangga.

[8] Subekti Wirawan, Hubungan Antara Kepemimpinan Kepala Sekolah Dan Budaya Organisasi dengan Kinerja guru,2010 (Tesis).

[9] Suharto, Hubungan Antara Kepemimpinan Kepala Sekolah Dan Kompetensi Kepribadian dengan Kinerja Guru, 2011, Bogor, Universitas Pakuan .

[10] Zeidner, M., Matthews, G. and Roberts, R.D.,2004. Emotional intelligence in the workplace: A critical review. Applied Psychology, 53(3), pp.371-399. 